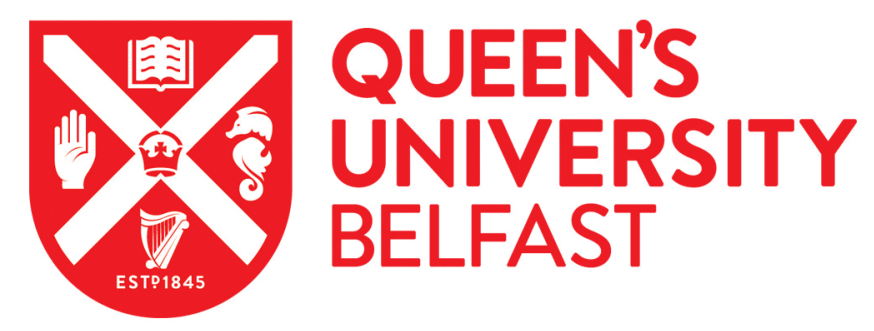

\title{
Freedom as non-domination: radicalisation or retreat?
}

McBride, C. (2015). Freedom as non-domination: radicalisation or retreat? Critical Review of International Social and Political Philosophy, 18(4), 349-374. https://doi.org/10.1080/13698230.2015.1033864

\section{Published in:}

Critical Review of International Social and Political Philosophy

\section{Document Version:}

Peer reviewed version

\section{Queen's University Belfast - Research Portal:}

Link to publication record in Queen's University Belfast Research Portal

\section{Publisher rights}

(C) 2015 Taylor \& Francis

This is an Accepted Manuscript of an article published by Taylor \& Francis in Critical Review of International Social and Political Philosophy on 18 June 2015, available online: http://www.tandfonline.com/doi/full/10.1080/13698230.2015.1033864.

\section{General rights}

Copyright for the publications made accessible via the Queen's University Belfast Research Portal is retained by the author(s) and / or other copyright owners and it is a condition of accessing these publications that users recognise and abide by the legal requirements associated with these rights.

Take down policy

The Research Portal is Queen's institutional repository that provides access to Queen's research output. Every effort has been made to ensure that content in the Research Portal does not infringe any person's rights, or applicable UK laws. If you discover content in the Research Portal that you believe breaches copyright or violates any law, please contact openaccess@qub.ac.uk. 


\title{
Freedom as non-domination: radicalisation or retreat? ${ }^{*}$
}

\author{
Cillian McBride
}

School of Politics, International Studies, and Philosophy, Queen's University Belfast, Northern Ireland

Keywords: non-domination, autonomy, equality, freedom, republicanism, structural domination

Republican political theory has undergone a remarkable revival in recent decades. This revival has its roots in explorations of the historical language of classical republicanism (Pocock 1975, Skinner 1978, 2008) but has now flowered into a vibrant and flourishing project within normative political philosophy, a project which has been gathering pace since the publication of Philip Pettit's Republicanism in 1997. To be sure, some strands of this revival are independent of Pettit's project, such as the republican liberalism of Dagger (1997) or the 'political' constitutionalism of Bellamy (2007), while others have sought to extend and develop aspects of Pettit's conception. Cecile Laborde, for example has sought to develop the connections between republicanism and feminist social criticism (2008, p. 23) and also to explore the possibility that it might contribute to debates on global justice (Laborde 2010, Bohman 2004). Frank Lovett, like Pettit himself in On the People's Terms (2012) and Just Freedom (2014), has outlined a republicanism which not only addresses the traditional themes of freedom and constitutional government, but which also addresses the theme of social justice (Lovett 2010) arguing for a conception of justice as the minimisation of domination. We are at the stage now in this republican revival when the central ideas of neo-republicanism, notably the idea of freedom as non-domination, are beginning to proliferate into new areas and adopt new forms as ever more theorists seek to extend and develop the neo-republican project.

On the one hand, these developments may pose a threat to the distinct identity of the republican project as cross fertilisation between a wider range of debates and traditions of thought takes place, but, on the other hand, this process can also be seen as presenting new opportunities to enrich both republican thought and related traditions such as liberal egalitarianism and critical theory. What is distinctive about this neo-republican revival is its focus on freedom as independence rather than on freedom as political participation (Pettit 1997, p.8). The contemporary republican revival is essentially a revival of the neo-Roman tradition rather than of the perfectionist, populist, neo-Athenian tradition that defines citizenship in terms of one's capacity to take turns in participating directly in collective self-government (Laborde and Maynor 2008, p.3). This latter form of republicanism is best exemplified in the work of Hannah Arendt (1958) and in that of more communitarian critics of liberalism (Sandel 1982, 1984, Barber 1984). Philip Pettit's key contribution, which places him at the centre of this revival of neo-Roman republicanism is his development of a theory of freedom, freedom as 'non-domination', which is distinct from both the ideal of negative liberty associated with the liberal tradition, or some strands of it at least, and from positive freedom, associated by Berlin (1969), rather indiscriminately perhaps, with collective self-determination, and individual autonomy. As Henry Richardson has argued, the centrality of Pettit's conception of freedom as non-domination to contemporary republicanism is explained by the fact that it offers a normative grounding for a tradition that has tended to focus rather narrowly on legal and institutional mechanisms (Richardson 2006, p. 176).

\footnotetext{
*Email: c.mcbride@qub.ac.uk
} 
In what follows, I will explore, firstly, the relationship of this ideal of freedom to its rivals and, secondly, offer some reflections on the relations between freedom as non-domination and related ideals of social equality. This last is especially pertinent now that Pettit has begun to present his theory, not only as 'a theory of freedom and government' (Pettit, 1997) but also as a general theory of social justice (Pettit 2012, 2014, Lovett 2010). This move signals a significant expansion of neo-republican ambition and a new phase in the republican revival in which we may expect to see the idea of freedom as non-domination being taken up in a variety of new contexts. I hope to identify some of the key challenges which freedom as non-domination must address if it is to play a central, radicalising, role in contemporary theories of democracy and social justice.

Pettit's republican political theory has three dimensions: the ideal of freedom as nondomination; the wider republican account of constitutional democracy; and an overarching consequentialist moral framework. I will suggest that if freedom as non-domination is to address the challenges entailed in developing a broadly egalitarian theory of social justice, some disaggregation of these dimensions may be necessary. It will be suggested, in particular, that the possibility that embedding freedom as non-domination within a larger theory of egalitarian justice may be more easily achieved by detaching it from this consequentialist framework. I will suggest, however, that it will not be possible to disaggregate freedom as non-domination from Pettit's conception of democracy, however, although we may now need to reinterpret its relationship to the ideal of collective autonomy. It is impossible to give a comprehensive account of Pettit's extraordinarily rich republican political theory here, so I will focus on three key issues: firstly, the relationship between freedom as non-domination and rival conceptions of freedom, particularly collective autonomy; secondly, the relationship between the non-domination and structural domination and inequality; and thirdly, the prospects of freedom as non-domination to encompass all of the concerns which we might want an egalitarian theory of justice to address. My aim here, is not to seek to undermine the claim that freedom as non-domination is a distinctive and attractive ideal - a claim I endorse - but to explore the potential for the further development of the ideal.

For his part, Philip Pettit, has argued for the distinctiveness of the republican project from both neo-Athenian republicanism, on the one hand, and from contemporary liberal political theory, on the other hand. The gulf between communitarian, neo-Athenian republicanism, seems, however, far greater than any gulf between neo-Roman republicanism and contemporary liberalism (Larmore 2006, Richardson 2002, 2006). There are two features of the neo-Athenian tradition to which Pettit objects. Firstly, there is the 'populist' emphasis on freedom as collective political participation (Pettit 1997, p.201) and secondly there is the perfectionism typically endorsed by writers in this tradition, which insists that the life of the active citizen is the best, most choiceworthy, life for anyone to lead. This perfectionism has made it attractive to communitarian critics of the 'atomism' of modern social life (McBride 2013). While Pettit suggests, initially, that his republicanism is, in some sense, a 'communitarian' project (1997, p.8), it is not communitarian in the standard sense, but only insofar as he has a holist social ontology and regards freedom as non-domination as a common good which must be jointly produced by the members of a political community if any individual members are to enjoy freedom from domination. In contrast to communitarian thinkers, Pettit's position reflects an underlying moral individualism and a commitment to ethical pluralism which renders it incompatible with neo-Athenian perfectionism.

Consequently, Pettit's insistence that his version of republicanism is also distinct from liberalism, is a little surprising. His moral individualism and resistance to perfectionism, seem to place him squarely on the liberal side of the fence. Like other members of the liberal family, Pettit worries about the state's potential for dominating its citizens, arguing that we must be protected 
both against private domination (dominium) and public (imperium) (2014, p.77). He does not, however, endorse the sort of impartialist liberalism associated with the Kantian, contractualist tradition that arguably represents the mainstream of contemporary liberal political philosophy. Rather, he adopts a freedom-centred consequentialism which commits the state to the active promotion of freedom as non-domination, but which does not entail the view that non-domination is in any sense a candidate for the good life. Rather, it functions more as a background condition ensuring citizens have the space to exercise undominated choice. This is a relatively novel position, in political philosophy at least, although, as we shall see below, it may, arguably, pose some problems for the development of republican theories of justice. The real gulf, as Pettit sees it, between his republicanism and liberalism, is the commitment of liberals to negative liberty.

While freedom as non-domination appears to sit somewhere between Berlin's conceptions of negative liberty and positive freedom as a third conception of freedom, it is most sharply opposed to negative liberty (but see Carter 2008). This is true even though freedom as non-domination itself is primarily focused on external, rather than internal threats to freedom, i.e. on the problem of external interference rather than on self-mastery. Where the negative liberty view regards one as unfree only where one is subject to actual interference (Berlin 1969, p. 122), from the perspective of freedom as non-domination this is doubly mistaken. Firstly, the absence of deliberate external interference is not sufficient to ensure one's freedom. Secondly, the presence of such interference does not necessarily render one unfree (Pettit 1997, p. 23). The first of these points can be explained with reference to the example of the pampered slave in a Roman household, free to do as he pleases and not subject to the violent interference typically associated with slavery. This slave is not subject to direct interference but on the non-domination account he is not therefore free. This is because he enjoys this freedom at the pleasure of his master, who may choose to interfere with him at any time should he choose to do so. To be free from interference but not from the possibility of interference by another is to be dominated: 'One agent dominates another if and only if they have a certain power over that other, in particular a power of interference on an arbitrary basis.' (Pettit 1997, p. 52). Negative liberty is insensitive to the problem of domination: the problem that one may be in another's power without that person having to actively interfere with you. On the negative liberty view all actual interference entails a loss of liberty, while on Pettit's view, this is true only in the case of 'arbitrary' interference. The interference of the law, in principle, need not entail a loss of liberty in his view, if the system of regulation serves to secure citizens from domination. The negative liberty and freedom as non-domination conceptions of freedom give rise to directly opposed stances on the relationship between freedom and law.

While Hobbes provides the first clear statement of the negative liberty position - that 'liberty is the silence of the law' - Bentham, Pettit observes, regards it as his own 'discovery' and ensures its central role in the development of classical liberalism in the nineteenth century (Pettit 1997, p. 44, 2014, p. 14). Pettit suggests that negative liberty struck Bentham as attractive precisely because it offered a relatively undemanding conception of freedom. This was not, interestingly, because Bentham et al. simply placed a low value on freedom, Pettit suggests, but rather because of a concern with the extent to which freedom could realistically be equalised amongst citizens. Negative liberty, being relatively undemanding could be enjoyed by servants as well as masters and served as a good candidate for this project. The older tradition of freedom as non-domination, if extended to all, would clearly present an unambiguous threat to the social order of the day by threatening the very relationship of master and servant (Pettit 2014, p. 16). In this way, liberalism's universalist project became wedded to a relatively thin conception of freedom and republican freedom was effectively lost from modern political thought. This is a compelling narrative, but 
republicanism will only be distinct from liberalism if it can be shown that liberalism is exclusively committed to the negative liberty view.

Pettit acknowledges that the early history of liberalism is rather messier than this narrative suggests: Locke clearly opposes the exercise of arbitrary power in the Second Treatise, for example (Pettit 2014, p. 93). He does not, however, give much weight, in his account of the relationship between republicanism and liberalism, to the Kantian strain of liberalism. In this, he appears to follow Berlin in neglecting the way liberal politics can be justified with reference to the ideal of equal respect for our status as autonomous persons. Republicanism, arguably, does not die with the rise of Utilitarianism, but is transformed by Rousseau and Kant, living on in contemporary liberalism in the idea of a political community of free and equal persons. Pettit does, of course, have philosophical reasons for rejecting autonomy as a political ideal, but the narrative of the occlusion of republicanism by negative liberty tends to suggest that republicanism and contemporary liberalism have less in common than is, perhaps, the case.

While the existence of a clear gap between Pettit's republicanism and right-liberals, or libertarians, is undeniable (Brennan and Lomasky 2006, p. 222) it is less clear that there is such a clear gap between this style of republicanism and 'left' liberalism (1997, p. 9-10). Pettit suggests that Rawls, for example, adheres to a purely negative liberty view of freedom (1997, p. 50), although Rawls himself is happy to insist on the affinities between his position and that of 'classical republicans' (1993, p. 205). Rawls, in a move which parallels the neo-Roman/neo-Athenian contrast, stakes out a clear distinction between his liberal/republican position and that of 'civic humanists', whose perfectionism is incompatible with the pluralism of political liberalism. Furthermore, in response to Habermas, Rawls argues that he is not committed only to the liberty of the moderns, i.e. personal autonomy, but also to collective autonomy and that liberalism, 'properly interpreted', treats each of these as 'co-original and of equal weight' (1993, p. 412). In this way, the attempt to demarcate neo-Roman republicanism from contemporary liberalism seems not entirely successful and some have argued that not only is liberalism more 'republican' than Pettit is usually prepared to allow, Pettit's own position is itself also more fundamentally liberal than he is prepared to admit (Larmore 2003, p. 115).

In more conciliatory moments Pettit has suggested that one way to view the relationship between his version of republicanism and liberal egalitarianism is not as an 'outright rejection' of that position but rather as a 'radicalisation' of it $(1993$, p. 304). Does it really matter at the end of the day whether we think of these as distinct, almost entirely self-contained, traditions, or see them rather as families of related arguments sharing many elements in common? I am inclined to think that this latter perspective may be more fruitful in the long run as it creates a space in which to explore the relations between non-domination and other dimensions of political freedom on the one hand, and between non-domination and other important values, on the other. This way of thinking about the relations between republicanism and liberalism, rather than representing a loss of clarity, would rather serve as a precondition of developing new 'hybrid' theories in which non-domination may play more or less central roles and it may be necessary if freedom as non-domination is to play a radicalising role in contemporary political theory.

\section{Dimensions of freedom}

While negative liberty and freedom as non-domination appear to be mutually exclusive, the relationship between non-domination and autonomy is more complex. Pettit has been criticised for 
presenting non-domination as the 'true meaning' of political freedom (Larmore 2003, p. 103) and for failing to adopt a sufficiently pluralist approach to freedom and other values. This is surprising in some ways, as Pettit claims that freedom as non-domination is 'ecumenical' in the sense that it is not taken to exclude other values, but is a 'primary good' which we have reason to want, whatever else we may want $(1997$, p. 91). Indeed, in presenting freedom as non-domination as a 'political' rather than a personal ideal, there are clear parallels with Rawlsian political liberalism. This is particularly apparent in Pettit's account of the relationship between non-domination and personal autonomy. Autonomy, i.e. freedom as self-mastery, is not regarded by Pettit as fundamentally at odds with non-domination in the way that negative liberty is. Rather, it is confined to the private sphere as a personal ideal, rather than one which the state should be concerned to promote:

Freedom as personal autonomy may be a very attractive value, perhaps even an intrinsic good; indeed I am myself committed to a version of the autonomy ideal that I describe as 'orthonomy'. Freedom as personal self-mastery, however, is a richer ideal than that of freedom as non-domination; there can certainly be non-domination without personal self-mastery, but there can hardly be any meaningful form of self-mastery without non-domination. (1997, p. 81-2)

Whether or not citizens are concerned to develop their capacity for autonomy, freedom as non-domination will protect their opportunities to develop this capacity, should they choose to do. The state, however, will be restricted to promoting non-domination, leaving autonomy to the private sphere. In contrast to personal autonomy, all citizens have an interest in non-domination, regardless of their larger ethical commitments. That said, Pettit's account of the relationship of the different dimensions of freedom is more systematic than the 'privatising' of personal autonomy suggests. He is committed to the idea, for example, that human agency at this level is a matter of being in 'discursive control' of oneself $(2001$, p. 65$)$ such that autonomy/orthonomy is cannot be viewed simply as one conception of the good life amongst others. Agents have some basic interest in autonomy/orthonomy regardless of the role it may also play as an ethical ideal. In this way, Pettit's ecumenical republicanism does not travel as lightly as Rawlsian political liberalism. While it is underplayed in Pettit's strictly political theory, there is in fact a systematic, multi-layered account of freedom at work in the background.

With collective autonomy, the situation is, however, rather different as this appears to challenge freedom as non-domination on its own ground, i.e. as a rival political conception of freedom. Pettit has, accordingly, placed the issue of 'populism' at the centre of his rejection of neoAthenian republicanism (1997, p. 8, p. 201). More recently, he has extended this opposition to the 'communitarian' commitment to collective autonomy reflected in the work of Rousseau and Kant (2012, p. 11-15) in which citizens exercise collective self-mastery through their participation in collective self-legislation, rather than through taking turns in direct self-rule. Opposition to this 'populism' motivates Pettit's emphasis on the value of contestatory devices such as courts rather than participatory institutions, whether direct, or indirect (1997 pp. 183-200, 1999, 2012, p. 15)

Can Pettit maintain a clear division between freedom as non-domination and collective autonomy? There are reasons to think that this line will be difficult to maintain. Recent revisions to the account of domination in On the People's Terms appear to have significantly enhanced the role of something like collective autonomy within the theory. As noted above, a key feature of the theory is the claim that not all interference counts as dominating. While for those committed to negative liberty, more law must mean less liberty, Pettit argues that this is not necessarily true: the law can serve to protect us from private domination. While legal constraints may indeed entail interference with an individual's negative liberty, they do not necessarily dominate, but may protect our freedom from domination by denying others the power to interfere with us at will. In this way, law protecting 
worker's rights may interfere with the negative liberties of employers, but may secure workers from arbitrary dismissal, and thereby protect them from domination. The key to distinguishing between acceptable and unacceptable forms of interference lies in the idea that some interference may be arbitrary while other forms of interference may not be.

Arbitrariness has been central to Pettit's account of domination hitherto. It captures the bad of being subject to the will of another. To vindicate the claim that not all interference is objectionable Pettit needs to give a clear account of what is to count as arbitrariness and he does so by appealing to the idea that non-arbitrary interference must in some way track the interests of those subject to interference:

Under this conception of arbitrariness, then, an act of interference will be non-arbitrary to the extent that it is forced to track the interests and ideas of the person suffering the interference. Or, if not forced to track all of the interests and ideas of the person involved - these may make inconsistent demands - at least forced to track the relevant ones. (1997, p. 55)

One problem with focusing simply on tracking the interests of the persons to be interfered with is that this would permit benevolent dictatorship, in which laws were designed to track the interests of the governed, but the people themselves had to part to play in making, or contesting, these laws (Brennan and Lomasky 2006, p. 241).

The account of arbitrary interference given above does not rely solely on the idea of tracking the interests of the governed, however: it also stresses that the laws must be 'forced' to do so and in Pettit's latest account of non-domination it is this element which has come to the fore. Pettit suggests that the term 'arbitrariness' is ultimately unhelpful because it suggests that the essential difference between acceptable and unacceptable interference is whether or not that interference is capricious or rule-governed $(2012$, p. 58). It is clearly undesirable to be subject to the caprice of another person, who may interfere with you on a whim, i.e. for no clear reason, but to focus on this feature would be to neglect the possibility that it would be equally undesirable to be exposed to rule-governed, and, strictly speaking, non-arbitrary interference. One might imagine a government pursuing a rigorously rule-governed policy of discrimination against some particular group, for example, which, in this limited sense would be non-arbitrary, but clearly morally objectionable. Pettit now proposes to define domination as the possibility of being exposed to 'uncontrolled interference' in one's affairs $(2012$, p. 58).

What this revision seems to have done, however, is not only to clarify how we are to draw the distinction between acceptable and unacceptable forms of interference, but also to make clearer the way in which the practice of non-domination appears to depend upon some form of collective autonomy. To be secure from private domination, i.e. domination from other social actors it is enough to enjoy the protection of the law, but to be secure from public domination, i.e. domination from the state itself, we need to exercise control over the state ourselves. To entirely cede our control of the state to some other institution like a supreme court, or to some subset of citizens would seem to expose us once more to domination by exposing us to the possibility of uncontrolled interference by some other actor (Pettit 2012, p. 281, McBride 2014). As Pettit argues, it is necessary that citizens 'share equally in democratic control of the state' $(2014, p .77)$. In this way, if we are to avoid public domination then some form of popular control, i.e. collective self-determination, is necessary. If this is so, then it cannot be the case that freedom as non-domination offers an alternative to the ideal of collective autonomy because it turns out that it ultimately depends on the ideal of a self-governing political community as a necessary condition of freedom as nondomination. 
This is not to suggest, of course, that freedom as non-domination simply collapses into the sort of 'populist' account which Pettit rejects. Rather, he has developed a distinctive account of collective self-determination which is institutional, non-majoritarian, and holist, and which does not moralise political participation in the way communitarian republicans do. In this account the populist notion that the 'people' exist independently of the political institutions which make it possible for them to form a collective will is rejected. Political institutions are not mere 'instruments' of the people's will, but are constitutive of their collective agency (1999). Simple majoritarianism is also rejected: each and every one of 'the people' must share in the exercise of collective control, minorities as well as majorities. In this regard Pettit makes common cause with Rawls and Habermas who share the view that it is a mistake to view constitutional restraints on the majority as involving a basic tension between rights and democracy. Rather these are to be understood as mutually supporting (Rawls 1993, Habermas 1998). This ideal of a political community of free and equal citizens, then, justifies the sort of counter-majoritarian measures Pettit defends under the banner of 'contestatory' democracy (Pettit 1999). This model of 'collective' agency is not to be confused, however, with the overly unified, 'corporate' model of popular sovereignty which animates Rousseauan populism (Pettit 2012, p. 13). This contributes, also, to a sort of holist approach to the institutions of democracy on which it is the interplay of a plurality of institutional devices, some involving popular participation, direct and indirect, and others playing a contestatory, invigilating, role on behalf of citizens, which together make collective self-rule possible. On this view it would be a mistake to try to distinguish between the 'democratic' parts of the constitution from the other institutions: it is the combination of electoral and contestatory institutions which makes effective control of the government possible (Pettit 2012, p. 195, p. 281). In this way, Pettit can plausibly be seen to have breathed new life into the old republican ideal of the 'mixed constitution' and outlined a distinctive, republican, way of thinking about collective self-government, which circumvents the old stand-off between communitarian accounts of participation and the constitutional protection of negative liberties. If non-domination does rely, ultimately, on some conception of collective autonomy, in doing so it directs us to a novel way of thinking about the practice of collective autonomy itself.

\section{Republicanism and social equality}

One of the most striking features of Pettit's account of domination is his account of the 'psychological profile' that it produces amongst those subject to it. The dominated, conscious of their subordinate position and their constant exposure to the insecurity which they experience, adapt by adapting ingratiating, servile postures with respect to those who dominate them $(1997, \mathrm{p}$. 60-1). This aspect of freedom as non-domination, then, has clear implications for how we think about social equality. There are clear affinities here between Pettit's work and that of Axel Honneth on the connections between social recognition and 'social' freedom $(1995,2014)$ : freedom from domination makes possible and relies in large part upon relations of equal respect (Honohan 2002, p. 257). As such, it also has affinities with attempts in recent years to refocus debates about economic equality away from a narrow concern with the role of luck and of individual responsibility in the distribution of economic resources, and back to a larger conception of 'democratic' or 'relational' equality (Wolff 1998, Anderson 1999, Scheffler 2003, Schemmel 2012).

Honneth argues that without appropriate relations of social recognition: love, respect, and esteem, individuals will be unable to develop the sorts of relations to themselves necessary to develop their capacity for self-determination and self-realisation: self-confidence, self-respect, and self-esteem (1997). While focused on the development of individual capacities, this account is 
'social' to the extent that it supposes that we cannot acquire these capacities independently of key social relationships and institutions: family, state, and market. Pettit's ontological holism similarly takes social relations to be essential to developing freedom as discursive control, on one hand, and for the enjoyment of freedom as non-domination on the other hand. Pettit, while interested in the way our sensitivity to social esteem can play a role in the regulation of individual and corporate conduct (Brennan and Pettit 2004), focuses on the centrality of relations of equal respect to freedom as non-domination:

In the received republican image, free persons can walk tall, and look others in the eye. They do not depend on anyone's grace or favour for being able to choose their mode of life. And they relate to one another in a shared, mutually reinforcing consciousness of enjoying this independence. Thus, in the established terms of republican denigration, they do not have to bow or scrape, toady or kowtow, fawn or flatter; they do not have to placate any others with beguiling smiles or mincing steps. In short, they do not have to live on their wits, whether out of fear or deference. They are their own men and women, and however deeply they bind themselves to one another, as in love or friendship or trust, they do so freely, reaching out to one another from positions of relatively equal strength. (2012, p. 82)

This ideal of citizens relating to each other as free and equal persons has obvious affinities with more Kantian notions of respecting others as autonomous members of the kingdom of ends: bound to others not by ties of affection or unequal dependence, but as equals with the moral power to call others to account and, by the same token, to be called to account by others, in turn. Just as Kant believes we have a duty to respect ourselves and avoid entering into servile relationships with others (Hill, 1991), the republican citizen will want to stand tall and look others in the eye. For those attracted to the Kantian ideal of equal respect, and of the moral community as a community of free and equal persons, the republican ideal of the free person will be an attractive model, possibly because of the way Kant himself was influenced by Rousseauan republicanism. While the injunction of the categorical imperative in the formula of humanity, to refrain from treating others simply as means to one's own ends, clearly captures the republican horror of being subject to the will of another, there may be a distinct advantage to approaching the application of such principles in the manner suggested by Pettit. It can be difficult to determine in a complex modern society just where the line is to be drawn between acceptable social cooperation and unjustly instrumental relations: what counts in concrete contexts as treating others simply as a means? Pettit has suggested that adopt what he calls the 'eyeball test' as a practical guide to the presence of domination:

I take the relevant yardstick to be set by what I call the eyeball test. At the level set by this test, the safeguards should enable people, by local standards, to look one another in the eye without reason for fear or deference.' (2012, p. 47).

The idea of local standards points us towards a contextual rather than metaphysical account of equal respect, which may prove to be the only realistic way to arrive at clear application of the formula of humanity. Pettit's account, then, may serve to enrich attempts to revive an understanding of equality as primarily a matter of establishing a community of free and equal persons and only secondarily as a matter of the fair distribution of economic resources, especially if the institutionalising of some of these ideas about fair distribution risk humiliating citizens (Wolff 1998).

This ideal of free and equal citizenship, while always the fundamental motivation of Pettit's republicanism, now has an explicitly load-bearing role in his formulation of the theory. Initially, reflections on the 'psychological profile' of freedom appear to have been directed at finding indicators of domination rather than as pointing to something to be regarded as wrong in itself (1997, p. 71). Similarly, reflections on the badness of the experience of insecurity which the dominated are subject to might be given a welfarist interpretation, rather than interpreted as a bad flowing from failure to respect others as equals. While Pettit has always sought to present non- 
domination as a strongly egalitarian project in some sense, $(1997$, p. 111) his consequentialism necessarily pushes equality into the background. That said, in more recent statements of the theory equality now plays a key role:

The republican approach strongly supports expressive egalitarianism. In this tradition, the ideal of the free citizen requires a civic status that enables each to stand on an equal footing with others. Such a status can be established only under a culture in which people are each prepared to accept such treatment and to claim no special privileges. [...] I shall assume that the expressive egalitarian constraint always applies. No proposals in any of these areas [justice, democracy, and sovereignty] can command support unless it is compatible with the principle that no one is special and all are to count as equals. (2014, p. 80)

While maintaining the position that freedom as non-domination does not require material equality, this 'expressive' egalitarianism, one rooted in the equal respect for persons now clearly functions as an absolute constraint on public policy and institutional design in much the way that it might in more Kantian, contractualist, theories, rather than merely as a means to promote nondomination. In this way, Larmore's claim, that the 'fundamental principle of respect for persons turns out [...] to constitute the deepest stratum in Pettit's republican theory' may be true, posing a question about the relationship between this commitment and his commitment to freedom-centred consequentialism (Larmore 2003, p. 115). Before exploring this issue, there is another challenge which egalitarian republicanism must face: the issue of structural domination.

\section{Can republicans recognise structural power?}

Cecile Laborde has sought to develop this republican model of social equality in ways that will forge connections with other forms of social criticism, like Marxism and feminism (2008, p. 23). This is a promising enterprise to the extent that while Pettit thinks of the free citizen as enjoying a certain kind of social status, he does not think of this status in purely legal terms. Rather, this is a social status which must be sustained both by certain institutional arrangements but also by the presence of appropriate social norms (1997, p. 241). To enjoy non-domination then, certain patterns of social recognition, primarily of respect, must obtain. As such, it is not hard to see how the ideal of freedom as non-domination might make a significant contribution to the work of social critics and critical theorists.

The critical theory tradition, however, with its ostensibly closer connections to empirical social science research, has long insisted on the effects of social structures on social life (Young 2006, p. 92). The idea that social structures can have a decisive impact on the lives of individuals and of social groups has long motivated egalitarian politics in all its varieties whether these structures are thought of as the institutions of the market and of private property, patriarchal social norms, ethnocentric and racist social attitudes, etc. It would seem to count strongly against the republican theory of freedom as non-domination if it were unable to take structural inequalities, and/or structural domination into account (Krause 2013). One reason to worry that non-domination may be ill-equipped to deal with the impact of social structures upon our situations may be that Pettit stresses the interpersonal nature of domination: to be dominated is to be subject to the will of another (2012, p. 49). Furthermore, he stresses that accidental obstructions to my choices cannot count as domination:

\footnotetext{
Were non-intentional forms of obstruction also to count as interference, that would be to lose the distinction between securing people against the natural effects of chance and incapacity and scarcity and securing them against the things that they may try to do to one another. This distinction is of the first importance in political philosophy, and almost all traditions have marked it by associating a person's freedom with constraints only on more or less intentional interventions by others. $(1997$, p. 53)
} 
We will return to the question of resourcing freedom shortly, but focus now on the relationship between individual agents and social structures: institutions and norms. As noted above, Pettit's outlook is clearly individualist rather than communitarian, but now we must ask whether his individualism is such as to exclude adequate acknowledgement of the impact of social structures on our lives? Pettit, it turns out, has long been concerned with this question. In earlier work he has distinguished two distinct issues in debates about the social nature of human agency: a contrast between 'individualism' and collectivism' and a second contrast between 'atomism' and 'holism' (1993, p. 118). The first contrast concerns the issue of whether or not individual agency is compatible with 'social structural regularities', of the sort stressed by sociologists, which are taken to count against the idea that we genuinely enjoy 'individual autarky' or control over our actions. The second contrast, between atomists and holists, concerns the question of how we acquire key capacities such as that for communication. On the one hand, those who adopt an atomist social ontology suppose that we can acquire such capacities independently of our social relations, while holists take the view that we can only acquire such capacities within social relations. On this question, Pettit clearly takes a holist position: freedom is a social status, and this turns out to be true all the way down to freedom as autonomy/orthonomy and beyond too. On the former question, however, he strongly resists the idea that social structures may 'override' or 'outflank' human agency and adopts an 'individualist' position (1993, p. 119). Does his individualism on this issue exclude structural effects on individuals or groups?

It seems that it does not. The collectivist position as Pettit characterises it, amounts to a denial that human beings are agents. Here he has in mind the sort of position that Hegel subscribes to when he claims that human beings are merely epiphenomena of the cunning of reason (Hegel 1975 , p. 89). In this vision, apparently, there are forces at work in human affairs that render human agency effectively illusory - a claim which continues to animate certain strands of thought in the social sciences and critical theory. Pettit's view, however, is not that there are no social structures, nor that they have no impact on individual agency, but rather, that their existence and the presence of such effects does not give us reason to suppose that agency is illusory. On the contrary, he acknowledges that social structures 'may exercise a reciprocal influence on those agents, structuring their perceptions, motives, and opportunities' (1993, p. 163). While some of these influences will be a cause for concern, the existence of social structures per se should not be regarded as incompatible with human agency, as Pettit conceives it.

In general then, Pettit is alive to the existence and impact of social structures and has a nuanced understanding of the way that social relations and social structures shape our capacity for and exercise of agency. That said, might social structures be taken to have impacts on our opportunities, say, that do not count as dominating effects on account of their impersonality? We might suppose that while domination pertains between persons, social structures might still produce social inequalities which may be more or less directly related to our freedoms, while not themselves dominating us. Lovett, for example, flatly rejects any suggestion that structures themselves may dominate us: 'I reject the view that structures themselves dominate people, as if there can be subjects of domination without there being also agents.' (2010, p. 25)

If we are to combine the idea of non-domination with that of structural constraints upon our lives, we can do so by enlarging the account of the agents of domination. From the outset, then, Pettit has stressed that agents may be both individual and collective:

I shall often speak as if there are just two individual persons implicated in cases of domination, but that is only for convenience. While a dominating party will always be an agent - it cannot just be a system or network or whatever - it may be a personal or corporate or collective agent: as in the tyranny of the majority, where the domination is 
never the function of a single individual's power. And while a dominated agent, ultimately, will always have to be an individual person or persons, domination may often be targeted on a group or on a corporate agent: it will constitute domination of individual people but in a collective identity or capacity or aspiration. (1997, p. 52)

If agency is not thought of as restricted to individual human beings, but may also be enjoyed by groups (as Lovett also supposes), then we can see how some sorts of social structures, namely institutions, may come to dominate us, to the extent that they may be, in effect, collective agents themselves. That Pettit and Lovett should account for structural domination in this way reveals a continuity between the republican project and older forms of thinking about social structures, all the way back to Marx's famous claim that the state was merely a committee for managing the collective affairs of the bourgeoisie. The idea that structural domination involves domination between groups of people has an established place within social and political thought. The inclusion of collective agents within Pettit's account looks like it allows him to extend his account of domination to include the sorts of structural effects which have concerned those in the critical theory tradition.

There is, however, a second reason to worry that Pettit's account of domination may not capture all of the things which we may be concerned about if we are concerned to identify structural obstacles to freedom. This is the 'common knowledge' condition, on which for relations of domination to obtain between persons, it must be a matter of common knowledge for the parties concerned (Pettit 1997, p. 60). This is to say that the powerful must be aware that they have power over others, and that these others are aware that they are in the power of the powerful, and that the powerful know that the powerless are aware of this, and so on. This might be thought to pose a problem to the extent that it might be thought that power can be exercised behind the backs of those who are subject to it, such that they are not aware that others have the power of uncontrolled interference over them. Those Marxist conceptions of ideology under which capitalist ideology serves to mystify social relations, obscuring their true nature from those participating in them, might appear to be excluded by this common knowledge condition, however. Even if we are reluctant to accept the Marxist analysis, we might think that the common knowledge condition is too demanding and that at least sometimes we might be mistaken about the degree to which we enjoy freedom as non-domination. We might, for example, only discover that we have been in the power of another when that power is exercised against us, i.e. when actual interference takes place. On the understanding of freedom as non-domination we have been unfree all along, of course, but it is only once interference takes place that our situation is revealed to us. It looks as if we may need to make room, then, for domination that is not a matter of common-knowledge, i.e. relations of domination that are not transparent to those participating in these relations.

We should not, however, simply dismiss the common-knowledge condition as misconceived. Firstly, it is essential to the existence of social norms or conventions (Lewis 1969) that those guided by them are aware that they pertain, and that they know that others are similarly aware, otherwise social norms would be unable to guide our expectations of others, and to shape their expectations of us (including our awareness that they have such expectations). Common knowledge is vital to the social norms that enable us to coordinate our interactions with others, and this is why Pettit insists upon this condition. Secondly, it is one of the distinctive features of this analysis of domination that it captures the way in which social norms play a central role in relations of domination, producing the sorts of deformations of character detailed above. The common knowledge condition captures the way that the expectations of the powerful and those of the powerless interact in order to produce the sorts of disrespect and adaptation characteristic of domination. The quality of social relations of subordination will not be picked up by accounts of power that insist on its anonymous, invisible quality and that would be a significant loss. Thirdly, as Pettit observes, even where those entangled in relations of domination are aware of the disparity of power involved, they may not 
view these hierarchical relations negatively. This suggests that the common knowledge condition does entail complete transparency after all, and can allow for some of the phenomena captured in older theories of ideological domination, that of the working-class Tory who accepts his lowly social position as entirely justified and who actively supports the maintenance of class hierarchy. This figure is aware of the relevant norms, but is happy to see his interest in equal freedom being subordinated to the demands of a hierarchical social order. Finally, Pettit expressly acknowledges that there may be exceptions to the common knowledge condition. While the social order may demand that the common knowledge condition pertains in most contexts, there may be situations in which the powerful really are in a position to manipulate choices behind the backs of the powerless, through agenda setting, such that the powerless are not necessarily aware that such manipulation has taken place $(1997$, p. 60$)$.

Pettit now explicitly distinguishes between 'structural' and 'relational' domination (2014, p. 53 ) to clearly mark the collective, institutional, dimension of domination and argues that republicanism is aimed at the 'negating the relational effects of [...] structural domination.' (2014, p. 54). In doing so, Pettit is underlining existing features of his account, rather than adopting a new direction, but it seems likely that there is still further work to be done on the role of structures in republican political theory. One issue is relates to the idea that domination, interpersonal or structural entails being subject to the will of another. While Pettit allows that collective agents may be subjects of domination, his account of collective agency is much stricter than Marx's. While classes may function as collective agents for Marx, from Pettit's point of view, it is not clear that they possess the necessary internal, institutional, structure necessary for forming a collective will (Pettit and List 2011). Pettit's examples of collective agents with the power to dominate include multinational corporations, churches, universities, and, of course states. In contrast to classes, genders, and races, etc. these are highly institutionalised collectivities, with clear mechanisms, democratic, or otherwise, for making collective decisions. In this way, there may still be a significant gap between the republican understanding of structural domination and those working in the various strands of critical theory.

One way to resolve this may be to extend the account of agency such that all structural impacts can be attributed to domination by some agent or other. It is not clear, however, that Pettit's relatively well-defined account of collective agency would lend itself to this approach and we might have reason to want to avoid stretching our account of collective agents in this way if it were to risk emptying the notion of any real content. Another, perhaps more promising avenue would be to stick to a relatively limited account of structural domination and to return to the distinction introduced above between different sorts of structural effect, some involving domination, and some producing inequalities which may be the products of unintended, aggregate, effects of human actions. Markets, which are not themselves agents, but contexts in which agents interact, for example, may perhaps have this latter sort of effect, while individual corporations may have the former, dominating, effect. Markets might, on this view, facilitate domination by corporate agents but would not dominate directly themselves. Such a move would allow us to distinguish between different sorts of structural effect: some objectionable in virtue of their role in sustaining domination, and others objectionable in others ways, notably their contribution to social inequalities, in health, for example, which may not be directly related to domination. A political theory centred on domination, however, might not be in a position to attach any significance to structural inequalities, rather than to structural domination, and this might prompt concerns about the narrow focus on such a theory and its capacity to offer a full account of social justice. 


\section{Consequentialism and egalitarianism}

For Pettit, while 'expressive' equality is essential, material equality is not. This is a common enough thought in theories of distributive justice: the moral equality of persons need not translate directly into the equal shares of resources, and just what this underlying equality actually demands is obviously the subject of ongoing dispute. The republican tradition has typically skirted such questions, and perhaps this is one of the factors which historically contributed to its occlusion not only by the idea of negative liberty, but by richer egalitarian ideas in the nineteenth century: a political tradition largely focused on recommendations about constitutional forms presumably appeared excessively narrow in focus when socialists aimed rather at human emancipation more generally.

While Pettit's republicanism started out as a normative theory of freedom and government, focused on the normative and institutional conditions of social and political freedom, he has now explicitly extended the remit of the theory to the issue of social justice. This is not surprising, insofar as the focus of the theory on social freedom, and on the threats posed by individual and corporate agents to the enjoyment of non-domination, ultimately necessitated a fuller account of social justice. The same could not be said of neo-Athenian republicanism with its much narrower focus on political participation. Republican justice centres on the conditions which make it possible for citizens to enjoy equal freedom from domination $(2012$, p. 81$)$ and does so by entrenching a set of basic liberties (2012, p. 103). Pettit argues that this is not simply a matter of adopting something like Rawls' liberty principle while rejecting the difference principle. Rawls, he claims, only needs to fall back on the difference principle on account of the inadequate account of freedom which animates the liberty principle. A republican theory of justice, with its richer account of freedom as nondomination will have no need for any additional distributive principle (2012, p. 123).

As we have seen, however, Pettit rejects material equality, in large part because he appears to regard it as somewhat utopian, and in any case, not required for the enjoyment of freedom as non-domination (1997, p. 117). What has become clearer, however, is that the enjoyment of nondomination requires not only institutional and normative conditions, but also material resources. Pettit now distinguishes between two ways in which our freedom of choice can be hindered: firstly, there is invasion of our choices through subjection to the will of another. We suffer this when others have the power to interfere with us whether directly, by threatening to penalise us for our choices, or indirectly, by manipulating our choice sets. A second way in which our freedom of choice can be hindered is though 'vitiating' factors. These turn out, rather surprisingly, to be unrelated to the dominating will of another. Vitiating factors are:

\footnotetext{
Any factors that deprive you of recourses required for freedom in that choice, or that limit the use to which you can put those resources, without imposing the will of another as to what you should do. Any factors, in other words, that impair or impede your capacity to use your resources for satisfying your will but without deriving from the intrusive will of another agent or agency. Thus any lack of personal, natural, or indeed social resources will vitiate your freedom of choice. (2012, p. 39)
}

While Pettit regards invasion, i.e. subjection to the will of another, as worse than vitiation, the inclusion of vitiating factors as hindrances to freedom, and the claim that we may have a claim in justice to the resources necessary to overcome these obstacles to my freedom of choice is significant, for it suggests that we cannot rely solely on freedom as non-domination to guide a theory of social justice. It also, I think, appears to open the door to giving some formal version of positive freedom, a role within Pettit's theory of justice, if we are committed to resourcing certain basic choices. 
On the one hand, Pettit has claimed that his republicanism does not exclude a concern with other values:

the republican theory of justice does not suggest that freedom as non-domination is the only value that matters, as a utilitarian theory might argue that utility is the only relevant value. What it holds, however, is that if we look after the requirements of equal freedom as non-domination then we will have looked after the requirements of many other values as well: for example, the value of enjoying functioning capabilities. (2012, p.127)

On the other hand, however, it is not immediately obvious that his underlying consequentialist framework is uniquely well suited to encompass a more pluralist approach to the goods with which a theory of social justice should be concerned.

Certainly, Pettit's freedom centred consequentialism is not open to the same sorts of objections to which utilitarianism is exposed. Some have claimed that it violates the separateness of persons, for example (Brennan and Lomasky 2006, p. 242). This objection is misconceived, however, insofar as it mistakes the relationship between consequentialism per se and the specific form of consequentialism which is utilitarianism. While utilitarianism is vulnerable to the separateness of persons objection in virtue of its focus on maximising the sum total of utility, Pettit's freedomfocused consequentialism seeks to maximise the freedom of distinct individuals, and as such does not obviously permit the sort of trade-offs which are so problematic in the case of utilitarianism.

Pettit has argued that one benefit of the consequentialist framework is that it allows for the maximisation, or at least, the promotion of its key value, freedom, rather than merely 'honouring' it as a more Kantian theory might, but it is not clear what this amounts to in the absence of any real commitment to quantifying gains in freedom, on the model, say of welfarist theories. In his most recent work, for example, qualitative tests are offered to guide our efforts to realise the ideal of freedom as non-domination, primarily, the 'eyeball test'. As indicated above, however, there is no reason why Kantians might not avail themselves of the 'eyeball test', which seems entirely consistent with non-negotiable expressive egalitarian constraints.

In the end, the consequentialist framework, while it appears to give freedom as nondomination a pre-eminent place in a theory of justice, may do so at the cost of drastically narrowing the scope of that theory, and diverting our attention from other key goods which we may be concerned with, whether these are other forms of freedom unrelated to non-domination, such as 'unvitiated' freedom of choice, or freedom as autonomy, not to mention other goods such as wealth or health. Pettit's consequentialist strategy is motivated in large part by the thought that only a consequentialist approach can offer a suitably realistic approach to justice, one that stands some chance of being implemented in the world we live in $(2012$, p. 1). In this, he shares the common view that Kantian, contractualist, theories will be too utopian to be of much practical value. Whether this concern is well-founded cannot be argued here, but the example of Benthamite 'realism' with respect to freedom itself may stand as a salutary warning about the risk of allowing realism to play too great a role in shaping the content of our normative theories, as opposed its role in informing our political practice.

The key question, however, is whether or not this consequentialist strategy ends up placing significant restrictions on the scope of a republican theory of social justice such that it risks amounting to a retreat from liberal egalitarianism rather than a radicalisation of it, as Pettit claims. His wager, in effect, is that the promotion of freedom as non-domination will encompass most of the concerns which animate contemporary egalitarianism, and even if material equality itself is not a goal, security from domination will still entail significant economic redistribution. This claim has some plausibility, and one which is likely to be explored in greater depth in coming years as the 
republican account of justice gains ground. Private domination extends deep into social life and its sources are many so there is much to be said for the idea that the promotion of freedom may end up capturing most of the territory of liberal egalitarianism.

On the other hand, however, there are good reasons to suppose that adopting a consequentialist approach which compels us to elevate freedom as 'the only guiding good' (Pettit, 2014, p.xix) may be too narrow in focus. Firstly, as we have seen, Pettit's republicanism relies heavily upon expressive egalitarianism as an absolute constraint. Secondly, freedom as non-domination must exclude a number of traditional egalitarian concerns. Scanlon, drawing attention to the variety of objections we may have to inequalities, suggests that a concern with domination may only explain some objections to inequality:

\footnotetext{
When inequality of starting points undermines the fairness of a process, domination of those who are placed at a disadvantage does not always result, since the process may confer no power but only honor or the opportunity for a more pleasant and rewarding life. Unfairness, however, remains, and can take several forms: some people can simply be excluded from competition, or background conditions such as inequalities in training and resources can render the competition unfair. $(2003$, p.205)
}

Underlying this account is the idea that the ideal of a community of free and equal citizens relies, at its base on the idea that all citizens are entitled to equal concern and respect. While one key form this takes is the ban on dominating others, as outlined above, it is not the only form which this takes and as such this commits us to a concern with the distribution of key goods, independently of any concern with their role as means of domination. Contractualism, for example may offer the prospect of a more pluralist approach to justice than consequentialism, in which freedom from domination may be one among a set of primary goods, rather than the pre-eminent good. This possibility can only be raised here, not defended, but it suffices to indicate the range of possibilities available to us for the further development of the ideal of freedom as non-domination.

\section{Exploring freedom as non-domination}

The contributions to this volume reflect the sorts of challenges facing the further development of the ideal of freedom as non-domination, assessing its relations to other dimensions of freedom, challenging the account of democracy associated with it, exploring affinities with related projects, and identifying challenges to its application to new problems such as workplace democracy and educational justice.

In his contribution, Philip Pettit presents a further exploration of some of the dimensions of freedom touched on above: the psychological, ethical, and political, thereby underlining the complex and multi-layered understanding of freedom which lies behind his republican account of political freedom. He argues that there are three dimensions of freedom which we can think of as related in the following way: freedom in the will, freedom of the will, and freedom for the will. The first of these, freedom in the will, is the psychological aspect of freedom and encompasses the basic capacity to deliberate about our choices, a capacity which human beings normally possess. To have freedom in the will is just to have a free will which warrants the distinctive sorts of social relationships which agents have to one another. Not everyone will be especially good at making deliberative choices, however. Those who can exercise their freedom of the will reliably can be said to enjoy freedom of the will, or autonomy. Here Pettit registers his long-standing reservations about the Kantian interpretation of autonomy, however, as rule by one's 'true' self, and indicates that he prefers to think of this form of freedom as rule by 'right belief' or 'orthonomy'. Finally, there is 
freedom for the will, which is the political dimension of freedom from subjection to the will of another: freedom as non-domination.

Arto Laitinen explores the affinities between Pettit's understanding of freedom and Hegel's own multifaceted account of freedom. That there should be affinities between these two projects is not, perhaps, as surprising as it may appear at first blush, for as we have seen above there are interesting connections between Honneth's essentially Hegelian account of social freedom and its institutional preconditions and Pettit's similarly 'social' understanding of freedom. Laitinen's exploration of these relations will have special relevance for those seeking to forge connections between republicanism and contemporary critical theory. While both Pettit and Hegel regard freedom constituted in some sense by social relations, freedom as non-domination appears as an essentially 'negative' conception of freedom (albeit not in the strictly Berlinian sense) compared to Hegel's, which presents social cooperation as itself a realisation of freedom. While their respective metaphysical starting points could not be more different, however, Laitinen argues that their conceptions of freedom ultimately have more in common than one might suppose, and that consequently, the practical has a degree of independence from the metaphysical, a conclusion perhaps more congenial to Pettit than it might have been to Hegel.

Andreas Busen focuses on Pettit's claim that his conception of freedom as non-domination is, in an important sense, 'non-normative'. What this means is that in assessing the presence and degree of domination in a given relationship, this will be essentially a factual matter rather than depending on any expressly moral criteria. Critics, Busen points out, have objected on the grounds that Pettit's contrast between arbitrary and non-arbitrary interference relies on the idea that nonarbitrary interference tracks the agent's interests. These cannot be identified, however, without appealing to expressly moral considerations. The result is that Pettit's account of domination cannot avoid entanglement in moral criteria and the question of whether or not someone is dominated or not will not be simply factual. On the one hand, Busen argues that, in part, Pettit's motivation for seeking a non-moralised account of domination is that of presenting his theory not only as a normative theory, but also as one which can serve as a 'research programme' in the social sciences, something like critical theory and that this motivates the search for a factual account of domination. On the other hand, however, Busen argues that in addressing the critics' challenge we need to distinguish sharply between the question of public domination, i.e. domination by the state, and private domination, i.e. domination by other social actors. The former, according to Pettit is a matter of legitimacy, while the latter is a matter of social justice. Busen argues that at the level of social justice Pettit relies on a 'pre-political' and therefore potentially controversial account of citizens' interests, while at the level of political legitimacy, he adopts a more thoroughly procedural account of the interests which public policy must be forced to track, and this his account of public domination is more secure against the charge that it relies on a problematically moralised conception of domination. Busen concludes however, that this may come at the price of lacking sufficiently clear criteria for evaluating the outcomes of the process of democratic contestation.

Christian Rostbøll, by contrast, is happy to endorse a robustly proceduralist conception of republican democracy, arguing for its superiority to outcome oriented epistemic accounts of democratic decision-making. He broadly endorses Pettit's attempt to provide a freedom-centred account of democracy, as an attractive alternative to equality centred accounts on the one hand and Aristotelian-perfectionist and Rousseauan populist accounts on the other hand. Rostbøll argues that while freedom as non-domination is preferable to these rival models of democratic freedom, it is weakened by the way that democracy is presented as playing a merely instrumental role in sustaining non-domination. Rostbøll argues that while Pettit thinks democracy must be relegated to 
this secondary role because it is not part of the definition of democracy, in fact, democracy is essential to freedom as non-domination, which could not be sustained by any other institutional arrangement (unlike Berlinian negative liberty, for example). As such, democracy should be regarded as intrinsically valuable and not merely instrumental to the promotion of freedom as nondomination. Rostbøll's analysis, then, echoes our discussion above about the potential limitations imposed upon republican political theory by nesting it within a consequentialist framework, which must, arguably, relegate important values to the role of means to promote freedom as nondomination.

Fabian Schuppert advances a social egalitarian critique of Pettit and Laborde's republicanisms, arguing that these have not engaged as fully with social egalitarian themes as one might have expected, given the increasing prominence of 'expressive egalitarianism' within Pettit's theory. Following the recent work of Anderson, Scheffler, Scanlon, et al. Schuppert presents social egalitarianism as primarily focused on the status of persons as free and equal members of society (and hence as only secondarily concerned with any particular distribution of goods). He points to the variety of ways in which persons can be affected by structural disadvantages, and the variety of ways in which agents' freedoms may be undermined by these effects, not all of which appear to involve domination in the strict republican sense. In particular, Schuppert thinks republicans need to be more sensitive to the threat posed to freedom by alienation, especially in the form of social relations which involve forms of misrecognition such as shame. Rather than reject freedom as nondomination, however, Schuppert proposes two key revisions. Firstly, the account of domination should drop the common knowledge condition so that it can draw on a more extensive account of structural disadvantage. Secondly, a more social egalitarian republicanism should include a commitment to a principle of non-alienation if it is to capture the full range of threats to our selfrespect which may, in turn, diminish our capacity for freedom.

Colin Macleod raises essentially egalitarian concerns about the adequacy of republicanism as an account of social justice. He advances his critique by means of an examination of the applicability of freedom as non-domination to the issue of educational justice. Expressing some surprise that such an important institution has hitherto received little attention from republicans in this neo-Roman tradition, he questions whether freedom as non-domination is a helpful perspective from which to approach the interests of children, who have not yet acquired the capacity of autonomous choice which freedom from non-domination might protect (a cost perhaps of denying autonomy any political value). As a theory of social justice, freedom as non-domination, he notes, seems closest to the sort of sufficientarianism espoused by Elizabeth Anderson, which requires the distribution of sufficient resources to allow citizens to acquire the relevant capacities for democratic citizenship, while above this threshold, inequalities are permitted. Macleod argues that an equivalent version centred on freedom as non-domination seems to be similarly narrow in focus and will be unable to address questions of justice pertaining to other features of children's educational experience, or issues pertaining to the expansion of their choices available to them (Pettit has always resisted the idea that the maximisation of non-domination might require distributing resources in order to ensure equally broad ranges of choices to all).

Keith Breen advances an unashamedly Aristotelian argument for workplace democracy. He argues, however, that arguments for 'workplace republicanism' such as those advanced by Hsieh have a clear advantage over the two standard arguments for workplace democracy: the 'psychological support' and 'parallel case' arguments. The first of these arguments claims that the hierarchical organisation of the workplace undermines workers' capacity for autonomy in general thereby undermining their capacity for political participation. The second of these arguments 
suggests the parallels between membership of the state and employment in an enterprise are sufficiently strong as to require the democratic organisation of the workplace. Breen argues that these arguments are problematic, the psychological support argument relying essentially on contingent, empirical, support, while the second is undermined by significant disanalogies between the two cases. While 'workplace republicanism' is an attractive alternative that addresses the serious problem of domination in the workplace, Breen argues that hierarchically organised workplaces also pose a threat to workers' capacity for self-realisation, i.e. their interest in positive freedom. To the extent that the conception of freedom as non-domination can address this concern, however, it does so by effectively smuggling in a concern with positive freedom under the guise of responding to the 'conditioning' (now 'vitiating') of freedom by strictly non-dominating considerations. While this does not mean that we should reject the ideal of non-domination, it does mean that we must recognise its limitations and appeal also to the richer ideal of positive freedom.

In their own ways, then, the contributions to this collection serve to advance our understanding of the complexity of freedom and of the challenges facing the ideal of freedom as non-domination as it is taken up in new contexts. Whether freedom as non-domination is developed as a rival to liberal egalitarian or critical theory approaches to freedom and justice, or whether we will see, in the coming years, the emergence of 'hybrids' accounts, it is clear that the idea of freedom as nondomination is here to stay.

\section{Acknowledgements}

Thanks to Keith Breen and Iseult Honohan for their extremely helpful comments, to Fabian Schuppert for our many discussions about recognition and republicanism, to Morten Nielsen for prompting me to think about structural domination, and to Jurgen De Wispelaere and to John Coggon for giving me an opportunity to talk about some of these themes at the Towards a Republic of Health workshop at the University of Southampton in May 2014.

\section{Notes}

1. Again, there is a parallel here with Honneth's project, for although, as Laitinen points out in this collection, there are differences between their social conceptions of freedom, both Pettit and Honneth argue, in a manner consistent with ethical pluralism, that freedom must be the central value in an account of social justice (Honneth 2014).

\section{Biographical Note}

Cillian McBride is Senior Lecturer in Political Theory at the School of Politics, International Studies and Philosophy, Queen's University Belfast, and is the author of Recognition. Cambridge: Polity Press, 2013. 


\section{References}

Anderson, E.S., 1999. What is the point of equality? Ethics 109(2). 287-337.

Arendt, H., 1958. The Human Condition. Chicago, Ill.: Chicago University Press.

Barber, B., 1984. Strong Democracy. Berkeley: University of California Press.

Bellamy, R., 2007. Political Constitutionalism. Cambridge: Cambridge University Press.

Brennan, G. and Lomasky, L., 2006. Against reviving republicanism. Politics, Philosophy \& Economics $5(2), 221-252$.

Berlin, I., 1969. Two Concepts of Liberty. In: Four Essays on Liberty. Oxford: Oxford University Press, 118-172.

Bohman, J., 2004. Republican cosmopolitanism. Journal of Political Philosophy 12(3), 336-352.

Brennan, G. and Pettit, P., 2004. The Economy of Esteem. Oxford: Oxford University Press.

Carter, I., 2008. How Are Power and Unfreedom Related? In: C. Laborde and J. Maynor eds. Republicanism and Political Theory. Oxford: Blackwell, 58-82.

Habermas, J., 1998. On the relation between the nation, the rule of law, and democracy. In: The Inclusion of the Other. Cambridge MA: MIT Press, 129-153.

Hegel, G.W.F., 1975. Lectures on the Philosophy of World History: Introduction. Cambridge:

Cambridge University Press.

Hill, T.E., 1991. Servility and self-respect. In: Autonomy and Self-Respect. Cambridge: Cambridge University Press, 4-18.

Honneth, A., 2014. Freedom's Right. Cambridge: Polity Press.

Honohan, I., 2002. Civic Republicanism. London: Routledge.

Krause, S., 2013. Beyond non-domination: agency, inequality, and the meaning of freedom.

Philosophy and Social Criticism 39 187-208.

Laborde, C., 2008. Critical Republicanism. Oxford: Oxford University Press.

Laborde, C. and Maynor, J. eds., 2008. Republicanism and Political Theory. Oxford: Blackwell.

Laborde, C., 2010. Republicanism and global justice: a sketch. European Journal of Political Theory 9(1), 48-69.

Larmore, C., 2003. Liberal and republican conceptions of freedom. Critical Review of International Social and Political Philosophy 6(1) 96-119.

Lewis, D., 1969. Convention. Oxford: Blackwell.

Lovett, F., 2010. A General Theory of Domination and Justice. Oxford: Oxford University Press.

Maynor, J., 2003. Republicanism in the Modern World. Cambridge: Polity.

McBride, C., 2013. Democratic participation, engagement and freedom. British Journal of Politics \& International Relations 15(4), 493-508. 
McBride, C., 2014. Democratic ownership and deliberative freedom. In: M. Barrett and Zani, B. eds. Political and Civic Participation. London: Routledge. (forthcoming)

Pettit, P., 1993. The Common Mind. Oxford: Oxford University Press.

Pettit, P., 1997. Republicanism. Oxford: Oxford University Press.

Pettit, P., 1999. Republican freedom and contestatory democratization. In: Shapiro, I. and Hacker-

Cordon, C. eds. Democracy's Value. Cambridge: Cambridge University Press, 163-190.

Pettit, P., 2001. A Theory of Freedom: from the psychology to the politics of agency. Cambridge:

Polity.

Pettit, P. and List, C., 2011. Group Agency. Oxford: Oxford University Press.

Pettit, P., 2012. On the People's Terms. Cambridge: Cambridge University Press.

Pettit, P., 2014. Just Freedom. New York: W.W. Norton.

Pocock, J.G.A., 1975. The Machiavellian Moment. Princeton N.J.: Princeton University Press.

Rawls, J., 1993. Political Liberalism. New York: Columbia University Press.

Richardson, H., 2002. Democratic Autonomy. New York: Oxford University Press.

Richardson, H., 2006. Republicanism and democratic injustice. Politics, Philosophy and Economics $5(7), 175-200$.

Sandel, M.J., 1984. The procedural republic and the unencumbered self. Political Theory 12(1), 8196.

Scanlon, T., 2003. The diversity of objections to inequality. In: The Difficulty of Tolerance. Cambridge: Cambridge University Press, 202-218.

Scheffler, S., 2003. What is Egalitarianism? Philosophy and Public Affairs 31, 5-39.

Schemmel, C., 2012. Distributive and relational equality. Politics, Philosophy \& Economics 11(2), 123148.

Wolff, J., 1998. Fairness, respect, and the egalitarian ethos. Philosophy \& Public Affairs 27(2), 97-122.

Young, I.M., 2006. Taking the basic structure seriously. Perspectives on Politics 4(1), 91-97.

Skinner, Q. (1978). The Foundations of Modern Political Thought. Cambridge, Cambridge University Press.

Skinner, Q. (1998). Liberty Before Liberalism. Cambridge, Cambridge University Press. 